\title{
ACTUAL NUTRITION OF SCHOOL STUDENTS DURING DISTANCE EDUCATION IN CONNECTION WITH COVID-19
}

Tapeshkina NV1,2 $₫$, Koskina EV², Pochueva LP², Popkova LV², Vlasova OP², Sitnikova EM²

${ }^{1}$ Novokuznetsk State Institute for Further of Physicians, Novokuznetsk, Russia

${ }^{2}$ Kemerovo state medical University, Kemerovo, Russia

\begin{abstract}
Healthy diet has a complex protective impact on physical well-being, it ensures optimal functioning of all processes in the child's body, especially during the pandemic. To assess actual dietary intake in secondary school students during remote learning due to COVID-19 quarantine and restrictive measures. Descriptive study aimed to assess actual dietary intake in 5th and 6th grade secondary school students aged 12-13 was carried out; the students lived in different mono-cities of Kemerovo region, and their parents had approved their participation in the study. Actual dietary intake was assessed using the 24-hour dietary recall ( $\mathrm{n}=40$ ). Comparison of the diet composition qualitative and quantitative characteristics was carried out based on the current sanitary regulations, as well as the latest issue of the Federal Research Centre of Nutrition, Biotechnology and Food Safety guidelines. Insufficient intake of fish and seafood, eggs, milk and dairy products, vegetables, fruit, and juices was revealed in children. The daily diet included excessive amounts of bakery products, pasta, sausage products, confectionery products, and sugar. Energy value of the diet in secondary school students exceeded physiological requirements recommended during quarantine. The diet was unbalanced in terms of micronutrient content: along with sufficient contribution of protein and carbohydrates to the total calorie value, the excessive amount of fat together with insufficient amount of vegetable fat was detected. The eating pattern shaped during homestay lead to insufficient intake of micronutrients (vitamins B1, B2, PP, A), as well as to imbalanced intake of phosphorus, calcium, magnesium, and sodium. The study has shown that the diet of secondary school students staying at home due to quarantine does not confirm with healthy eating principles and is not rational in terms of the food product set.
\end{abstract}

Keywords: set of food products, physiological norms of consumption, schoolchildren, actual nutrition

Author contribution: The concept and design of the study - Tapeshkina NV, Koskina EV; collection and processing of material —Tapeshkina NV, Pochueva LP: statistical processing — Vlasova OP, Sitnikova EM; text writing — NV Tapeeshkina, EV Koskina; editing — Pochueva LP, Popkova LV Approval of the final version of the article, responsibility for the integrity of all parts of the article - all co-authors.

Compliance with ethical standards: Voluntary informed consent was obtained for each participant. The online survey was conducted on a voluntary basis using an online service. The conducted research does not endanger the participants and complies with the requirements of biomedical ethics

$\triangle$ Correspondence should be addressed: Natalia V. Tapeshkina

Stroiteley Ave., 5, Novokuznetsk, 654005; natasha72.03.24@mail.ru

Received: 16.03.2021 Accepted: 25.03.2021 Published online: 29.03.2021

DOI: 10.24075/rbh.2021.004

\section{ФАКТИЧЕСКОЕ ПИТАНИЕ ШКОЛЬНИКОВ В ПЕРИОД ДИСТАНЦИОННОГО ОБУЧЕНИЯ В СВЯЗИ С COVID-19}

\author{
Н. В. Тапешкина ${ }^{1,2}$, Е. В. Коськина², Л. П. Почуева ${ }^{2}$, Л. В. Попкова², О. П. Власова², Е. М. Ситникова²
}

' Новокузнецкий государственный институт усовершенствования врачей, Новокузнецк, Россия

${ }^{2}$ Кемеровский государственный медицинский университет, Кемерово, Россия

Рацион здорового питания оказывает мультикомпонетное протективное влияние на состояние здоровья, обеспечивает оптимальное функционирование всех процессов в организме ребенка, особенно в период пандемии. Изучить фактическое питание школьников среднего звена обучения в период карантинных ограничительных мероприятий по COVID-19, обучающихся дистанционно. Проведено выборочное исследование по оценке фактического питания школьников среднего звена обучения 5-7 классов в возрасте 12-13 лет, проживающих в разных моногородах Кемеровской области, родители которых дали согласие. Фактическое потребление пищи изучалось методом 24-часового воспроизведения питания $(n=40)$. Сравнение качественных и количественных характеристик состава пищевого рациона проводилось на основании действующих норм санитарного законодательства и вновь изданных методических рекомендаций ФГБУН «Федеральным исследовательским центром питания, биотехнологии и безопасности пищи». Результаты. В питании детей отмечается дефицит потребления рыбы и морепродуктов, яиц, молока и молочных продуктов, овощей, фруктов, соков. В суточных рационах в избытке хлебобулочные и макаронные изделия, колбасные и кондитерские изделия, сахар. Энергетическая ценность рационов питания школьников превышает нормы физиологической потребности, рекомендованные в период карантина. Питание разбалансировано по содержанию макронутриентов: на фоне достаточного вклада белков и углеводов в общую калорийность рационов выявлен избыток жиров, недостаток квоты растительных жиров. Сформированная дома модель питания школьников привела к дефициту поступления с рационом микронутриентов: витаминов В1, В2, РР, А, а также к дисбалансу потребления фосфора, кальция, магния и натрия. Проведенные исследования выявили, что рацион питания школьников во время пребывания дома на карантине не отвечает принципам здорового питания, нерационален по продуктовому набору.

Ключевые слова: набор продуктов питания, физиологические нормы потребления, школьники, фактическое питание

Вклад авторов: Концепция и дизайн исследования - Тапешкина Н.В., Коськина Е.В.; сбор и обработка материала -Тапешкина Н.В., Почуева Л.П.; статистическая обработка - Власова О.П., Ситникова Е.М.; написание текста - Тапешкина Н.В., Коськина Е.В.; редактирование - Почуева Л.П., Попкова Л.В. Утверждение окончательного варианта статьи, ответственность за целостность всех частей статьи — все соавторы.

Соблюдение этических стандартов: Добровольное информированное согласие было получено для каждого участника. Проведение онлайнопроса проводилось на добровольной основе с использованием онлайн-сервиса. Проведенное исследование не подвергает опасности участников и соответствует требованиям биомедицинской этики.

Для корреспонденции: Тапешкина Наталья Васильевна пр. Строителей, 5, Новокузнецк, 654005, Россия; natasha72.03.24@mail.ru

Статья получена: 16.03.2021 Статья принята к печати: 25.03.2021 Опубликована онлайн: 29.03.2021

DOI: $10.24075 /$ rbh.2021.004 
Today, there is a difficult global epidemiological situation due to spread of the novel coronavirus infection COVID-19. Countries take a number of sanitary-epidemiological and social measures to prevent the infection spread, from closure of social institutions and restaurants to transfer of schoolchildren and students to remote learning [1-3]. Numerous studies indicate that any precarious situation (changes in daily routine, dietary pattern, mode of study; the pandemic) may result in exertion of adaptation mechanisms and decline in children's functional capabilities [4-8]. Currently, adults must clearly understand that the immune response to infection would be determined by the family meal patterns and by the diet quality. After all, healthy diet has a complex protective impact on physical well-being. It underpins human vital activities ensuring optimal functioning of all bodily processes [9]. Achieving a perfectly healthy diet in adults and children is still a topical issue in our country. However, the other risk factors associated with quarantine measures cannot be excluded, such as uncontrolled access of children to information and communication technologies, diet violations in secondary school students, and insufficient physical activity. Nutrition remains a major environmental factor affecting the body's resistance to harmful environmental conditions $[10,11]$. Rational nutrition and balanced diet during the pandemic of the novel coronavirus infection COVID-19 provide the human body with essential vitamins and minerals. It has been found that vitamins A, C, D, E, B2, B6 and B12, folic acid, iron, selenium and zinc are essential to ensure the body's immunocompetence [12-15]. The foreign and national studies show that inadequate essential micronutrient supply results in reduced function of immunocompetent organs, as well as in the increased risk of infection and complications. During the pandemic, children must be provided with dietary protection against harmful environmental conditions by means of achieving safe and balanced diet at home based on the child's age-associated physiological needs.

To assess actual dietary intake in secondary school students during remote learning due to COVID-19 quarantine and restrictive measures.

Fifth- and sixth-grade secondary school students aged 12-13 studying in secondary general education institutions ( $n=40$ : 18 boys and 22 girls) were enrolled, who lived in different cities of Kemerovo region, and whose parents had approved their participation in the study. The randomly selected children were assessed individually at home in the presence of one of the parents using Zoom platform in October 2020. The novel coronavirus infection epidemiological features were the reason to use the Zoom platform. Inclusion criteria: age peculiarities, belonging to a Slavic ethnic group, remote learning for at least a week, existence of scales for weighting dishes or food products at home; one of the parents staying at home during the day. Children, who showed signs of acute respiratory disease during the survey period, were excluded from the sample.

Actual dietary intake of the children staying at home was assessed using the 24-hour dietary recall (24HR). The questionnaire was completed throughout the week. The rules for completing the children's food diaries were previously explained to parents, the "Album of Food Portion Sizes" allowing one to determine the size of food portions consumed by children was distributed [16].

The nutritional and biological value of the children's diet was evaluated in accordance with the existing regulations [17, 18]. In addition, the loss of nutrients during thermal food processing was taken into account. The consumed set of food products was compared with the set recommended by the Federal Research Centre of Nutrition, Biotechnology and Food Safety to children staying at home because of self-isolation or quarantine due to COVID-19 [19]. Statistical processing of the results was performed using the Statistica 6.0 software package based on the data distribution through calculation of the analyzed indicators' statistical characteristics (Me - median, 25; $75^{\text {th }}$ percentile - interquartile range); $p<0.05$ was considered to be statistically significant.

Self-isolation and quarantine measures due to global pandemic of COVID-19 modified the daily routine in both adults and school-age children. When staying at home with their children, the parents had to plan the food purchase carefully, preferably for a long time. At the same time, they had to create a meal plan, and to follow the family dietary pattern. The enforcement of children's self-isolation affects their level of physical activity. The latter decreases significantly relative to physiological needs in moving, and, as a consequence, results in energy consumption reduction by $200-400 \mathrm{kcal} /$ day and more in children aged 3-18 [18]. However, parents do not take this fact into consideration; the meal plan is created based on the family dietary habits.

Regardless of the epidemiological situation, the child's diet should include all traditional food products. The study results showed that the daily average food product set and the children's food intake during quarantine and self-isolation were not optimal. Comparison of food product set calculations for the children's diet is presented in Table 1.

Stereotypes toward eating behavior are developed in families. Both the choice between various food products and food preparation are directly influenced by parents. Analysis of the food product set during the pandemic revealed problems of various food products consumption, typical for many Russian families [4-6]. Overconsumption of pasta (by 140\% of the recommended dietary allowance), cereal grains and legumes (by $28 \%$ ), sausage products (by $173 \%$ ), confectionery products (by 64\%), and sugar (by 68\%) was detected in children during self-isolation. Access to food products and the presence of spare time allowed the children to make extra breaks for snacks (sandwiches, cookies, slices, gingerbread, etc.). Furthermore, the wait time between meals was reduced to 2.5-3 hours.

It is noteworthy that regardless of the recommended sausage products and sugar intake reduction during selfisolation, the average daily intake of those still exceeded the recommended dietary allowance by 2.7-3.2 times and 1.61.8 times respectively. Regardless of the epidemiological situation, the insufficient use of such food products as fish at home was detected. In the secondary school students, the fish consumption was reduced to $52-68 \%$ of RDA.

As we can see, the preference of poultry dishes had been shaped in children. The poultry intake exceeded the recommended daily allowance by 30-36\%/day. Consumption of cottage cheese reduced by $15 \%$ of recommended daily allowance, eggs by $45 \%$, and juices by $40 \%$ was detected.

Gastrointestinal tract is one of the most active microbial ecosystem of the body playing a vital part in immunological status. Therefore, probiotics, both contained in fermented dairy products and vegetables, fruit, cereal grains, would boost the child's immunity. However, it has been shown that the diet of the child staying at home is characterized by reduced intake of milk and fermented dairy products (by $26 \%$ of RDA), vegetables (by 27\%), and fruit (by 30\%).

The children's food intake analysis results are consistent with the previous studies conducted in the other regions of the country.

By the time of entering secondary school, the students' dietary habits have been already shaped. During self-isolation, cooking of main dishes and pastry is the most common, the 
Table 1. Average daily food product set, Me $(25 ; 75)$

\begin{tabular}{|c|c|c|c|c|c|}
\hline Food products & Absolute, grams $(n=40)$ & RDA, SanPiN & $\%$ of $\operatorname{RDA}(n=40)$ & RDA, Guidelines 2.3.1071-20 & $\%$ of RDA \\
\hline Wheat bread & $180(169 ; 210)$ & 200 & $90(85 ; 105)^{\star \star}$ & 180 & $\begin{array}{c}122 \\
(113 ; 149)^{\star *}\end{array}$ \\
\hline Rye bread & $40(35 ; 48)$ & 80 & $53(46 ; 72)$ & & \\
\hline Pasta & $48(41 ; 56)$ & 20 & $240(205 ; 280)$ & 20 & $240(205 ; 280)$ \\
\hline Cereal grains, legumes & $64(52 ; 66)$ & 50 & $128(104 ; 132)$ & 50 & $128(104 ; 132)$ \\
\hline Potatoes & $155(144 ; 175)$ & 188 & $\begin{array}{c}82 \\
(77 ; 93)^{\star \star}\end{array}$ & 160 & $\begin{array}{c}97 \\
(90 ; 109)^{\star \star}\end{array}$ \\
\hline Vegetables & $234(198 ; 257)$ & 320 & $73(62 ; 80)$ & 320 & $73(62 ; 80)$ \\
\hline Fresh fruit and berries & $130(108 ; 151)$ & 185 & $70(58 ; 82)$ & 185 & $70(58 ; 82)$ \\
\hline Fruit juices & $121(100 ; 156)$ & 200 & $60(50 ; 78)$ & 200 & $60(50 ; 78)$ \\
\hline Meat & $69(64 ; 78)$ & 78 & $88(82 ; 100)$ & 78 & $88(82 ; 100)$ \\
\hline Poultry & $69(49 ; 72)$ & 53 & $130(92 ; 136)$ & 53 & $130(92 ; 136)$ \\
\hline Sausage products & $41(31 ; 48)$ & 19 & $\begin{array}{c}215 \\
(168 ; 253)^{\star *}\end{array}$ & 15 & $\begin{array}{c}273 \\
(206 ; 320)^{\star *}\end{array}$ \\
\hline Fish (fillet) & $25(19 ; 37)$ & 77 & $32(24 ; 48)$ & 77 & $32(24 ; 48)$ \\
\hline $\begin{array}{l}\text { Milk, fermented dairy } \\
\text { products }\end{array}$ & $357(267 ; 388)$ & 480 & $74(55 ; 80)$ & 480 & $74(55 ; 80)$ \\
\hline Cottage cheese & $51(35 ; 60)$ & 60 & $85(58 ; 100)$ & 60 & $85(58 ; 100)$ \\
\hline Cheese & $11(7 ; 14)$ & 12 & $91(72 ; 116)$ & 12 & $91(72 ; 116)$ \\
\hline Sour cream & $12(7 ; 14)$ & 10 & $120(70 ; 140)$ & 10 & $120(70 ; 140)$ \\
\hline Eggs & $22(18 ; 35)$ & 40 & $55(45 ; 87)$ & 40 & $55(45 ; 87)$ \\
\hline Butter & $21(20 ; 27)$ & 35 & $60(57 ; 77)^{\star \star}$ & 25 & $84(80 ; 108)^{\star \star}$ \\
\hline Vegetable oils & $16(12 ; 16)$ & 18 & $89(67 ; 89)$ & 18 & $89(67 ; 89)$ \\
\hline Confectionery products & $41(29 ; 49)$ & 15 & $273(193 ; 327)^{\star *}$ & 25 & $164(116 ; 196)^{\star \star}$ \\
\hline Sugar & $42(38 ; 45)$ & 45 & $93(84 ; 100)^{\star \star}$ & 25 & $168(152 ; 180)^{\star \star}$ \\
\hline
\end{tabular}

Note: RDA — recommended dietary allowance according to SanPiN 2.4.5.2409-08 * RDA — recommended dietary allowance according to Guidelines 2.3.1071-20 ** — significant differences between groups $(p<0.05)$

intermediate goods (dumplings, Russian ravioli) are widely used. It has been found, that secondary school students do not limit themselves when choosing dishes and food products. They consume foods in accordance with the already shaped

Table 2. Nutrient composition of secondary school students' diet

\begin{tabular}{|c|c|c|c|}
\hline Nutrients & $\mathrm{PR}^{*}$ & Absolute $(n=40)$ & $\%$ of PR $(n=40)$ \\
\hline Energy value, kcal & 2400 & $2360(2067 ;$ 2534) & $98(86 ; 106)$ \\
\hline Protein, $\mathrm{g}$ & 72 & $71(69 ; 74)$ & $98(95 ; 103)$ \\
\hline Animal protein, $\mathrm{g}$ & 43.2 & $42(41 ; 45)$ & $97(95 ; 104)$ \\
\hline Fat, g & 80 & $92(87 ; 104)$ & $115(109 ; 130)$ \\
\hline Vegetable fat, g & 26.6 & $23(21 ; 25)$ & $86(79 ; 94)$ \\
\hline Carbohydrates, g & 348 & $335(301 ; 356)$ & $96(84 ; 102)$ \\
\hline Mono- and disaccharides, $\mathrm{g}$ & 60 & $82(80 ; 89)$ & $137(133 ; 149)$ \\
\hline Dietary fiber, g & 17.5 & $16(12 ; 17)$ & $93(68 ; 97)$ \\
\hline Thiamine $\left(\mathrm{B}_{1}\right)$, mg & 1.3 & $0,9(0,8 ; 0,96)$ & $69(67 ; 74)$ \\
\hline Riboflavin $\left(B_{2}\right)$, mg & 1.5 & $1,1(1,03 ; 1,17)$ & $73(77 ; 78)$ \\
\hline Vitamin C, mg & 65 & $67(60 ; 77)$ & $103(92 ; 118)$ \\
\hline Vitamin A, $\mu \mathrm{g} R E$ & 900 & $838(771 ; 908)$ & $93(86 ; 100)$ \\
\hline Niacin, mg & 18 & $15,3(13,6 ; 16,8)$ & $85(76 ; 93)$ \\
\hline Calcium, mg & 1200 & $689(646 ; 785)$ & $57(54 ; 65)$ \\
\hline Phosphorus, mg & 1200 & $1268(1173 ; 1271)$ & $105(97 ; 106)$ \\
\hline Magnesium, mg & 300 & $296(274 ; 317)$ & $99(91 ; 105)$ \\
\hline Iron, mg & 13.5 & $14(14 ; 16)$ & $104(104 ; 118)$ \\
\hline Sodium & 1100 & 2189 (1550; 2240) & $199(141 ; 204)$ \\
\hline
\end{tabular}

family dietary habits. Secondary school students also consume items not recommended to children of their age (mayonnaise dressing, ketchup, deep-fried buns, roasted potatoes, various spicy seasonings).

Note: $\mathrm{PR}^{*}$ — physiological requirements (average values for discussed age group). 
Nutritional diversity (adequate levels of main nutrients, dietary fiber, vitamins and minerals consumption) is the basis of the rational protective diet. Numerical values describing energy consumption and nutrient intake in children are presented in Table 2.

Due to reduced physical activity during self-isolation, the Federal Research Centre of Nutrition, Biotechnology and Food Safety recommended to reduce the daily calorie intake both in adults and children. In spite of the fact that physiological requirements $(\mathrm{PR})$ of secondary school students allow for daily calorie intake of $2400 \mathrm{kcal} /$ day, during self-isolation the children aged 7-18 are recommended to consume 1600-2000 kcal/ day. Based on the energy value, the actual daily average food intake did not exceed the PR. However, recommendations were not adopted; in the context of children's physical inactivity the energy value of the diet exceeded the values recommended to children self-isolating at home during quarantine by $18-47 \%$. Distribution of percentiles for a number of micronutrient intake values showed that significant (in terms of children's health) protein and animal protein content of the diet was within the normal range (95-105\%).

It should be noted that excessive amount of such foods as sausage products and mayonnaise dressing in the children's diet results in predominance of fats in the food. The fat content of the daily diet exceeded physiological requirements by 1.11.3 times. At the same time, compared to normal consumption of carbohydrates ( $96 \%$ of PR/day), the intake of mono- and disaccharides in children exceeded the recommended dietary allowance by $33-49 \%$ of PR. Reduced dietary fiber intake was revealed, the content of dietary fiber varied between 68-93\% of daily dietary allowance. The daily average consumption of protein, fat and carbohydrates was unbalanced (1:1.2:4.7).

Analysis of vitamin and mineral intake with food showed that the lowest daily average intake values were obtained for vitamin B1 (69\% of PR), vitamin B2 (73\% of daily dietary allowance), and vitamin PP (niacin) (85\% of PR). The intake of vitamins A (expressed in terms of retinol equivalents) and $\mathrm{C}$ was within the range of physiological needs. Analysis of mineral intake revealed reduced intake of calcium (to $35-46 \%$ of daily requirements) in secondary school students, along with excessive intake of sodium (the sodium level was elevated by 2 times on average). Adequate intake of phosphorus, magnesium and iron with food was detected. Normal absorption of calcium requires rational ratio to phosphorus, however, the level of phosphorus in foods consumed by children was 1.8 times higher than required. That reduced availability of calcium for absorption in the child's body.

\section{DISCUSSION}

The diet composition in secondary school students, forced to stay at home because of self-isolation due to COVID-19 and studying remotely, can be characterized as not optimal and not rational. According to the Federal Research Centre of Nutrition, Biotechnology and Food Safety guidelines, during the longterm homestay, the energy requirements should be reduced by means of reduced intake of some food products. During self-isolation, the insufficient physical activity is considered a risk factor for weight gain, as well as for impaired motor and evacuation function of the gastrointestinal tract.

However, due to access to food and presence of spare time in secondary school students, as well as to lack of set daily routine, and frequent breaks for snacks, the daily energy value of the food consumed was excessive; the nutrient composition of the food was unbalanced, since the children's dietary habits had not changed [11]. Regardless of the fact that protein and carbohydrate intake (absolute values) was close to normal, the fat intake was excessive. Analysis of vitamin and mineral intake in secondary school students revealed reduced absolute content of vitamins B1, B2, and calcium, along with excessive intake of sodium. This is in line with the results of previous studies carried out in other regions of the country during the period of epidemiological well-being. Results of a number of studies show that carbohydrate and fat rich dietary pattern is shaped in the modern secondary school students [20,21]. Analysis of foreign literature also provides evidence of health problems in foreign children due to malnutrition, eating disorders, etc. [22, 23]. The revealed imbalance of macro- and micronutrients is associated with insufficient intake of specific food groups. Thus, during self-isolation, the secondary school students have not managed to reduce the intake of salt, sugar, saturated and trans fatty acids at expense of the food products being the main source if those (bakery products, sweet sparkling drinks, nectars, various sausages, cheese with fat contents exceeding 30\%, mayonnaise, etc.) [19]. The secondary school students' daily diet included excessive amount of sausage products (by 2.1 times), confectionery products and sugar (by 1.6 times), pasta (by 2.4 times), bakery products (by 1.2 times). The diet was extremely scarce in terms of the amount of fish and seafood, eggs, milk and dairy products, vegetables, fruit, and juices. The secondary school students did not follow one of the major principles of rational nutrition, such as daily routine of eating. Parents paid little attention to menu planning based on the children's age peculiarities. Adjusting the supply of vitamins and minerals only through cooking traditional dishes and culinary display does not work.

Analysis of actual dietary intake in modern secondary school students, especially during the pandemic, remains of key importance, since the analysis results reflect home meal planning in families, as well as the impact of the regional socioeconomic situation. The study results showed that the secondary school students' diet during self-isolation at home was not optimal. The imbalance of macro- and micronutrient intake is associated with imbalanced food product set: excessive intake of high-fat foods, sugar, and confectionery products along with insufficient intake of fish, dairy products, vegetables, and fruit. Eating pattern and dietary habits of the family depend on the parents' education on nutrition, which should be taken into account when developing guidelines on optimizing nutrition. In order to adjust micronutrient composition of the secondary school students' diet, it is necessary to include specific food products, nutritional supplements, as well as complexes of vitamins and minerals boosting body's immune resistance during the pandemic.

\section{References}

1. Kuchma VR, Sedova AS, Stepanova MI, et al. Features of the vital activity and well-being of children and adolescents who study remotely during the epidemic of the new coronavirus

infection COVID-19. Voprosy shkol'noy i universitetskoy meditsiny i zdorov'ya. 2020;(2):4-24. Russian.

2. Viner RM, Russell SJ, Croker H, et al. 2020. School closure and 
management practices during coronavirus outbreaks including COVID-19: a rapid systematic review. Lancet Child Adolesc Health. 2020; (4):397-404.

3. Overview of public health and social measures in the context of COVID-19. Interim guidance. 18 May 2020. Available at: Downloads/WHO-2019-nCoV-PHSM_Overview-2020.1-eng.pdf. Accessed 16 April 2020.

4. Lebedeva UM, Battakhov PP, Stepanov KM, Lebedeva AM, Zankovsky SS, Bulgakova LI, Vinokurova DM Organization of nutrition of children and adolescents at the regional level. Voprosy pitaniia [Problems of Nutrition]. 2018; 87 (6): 48-56. DOI: 10.24411/0042-8833-2018-10066. Russian.

5. Sorokina AV, Giguz TL, Polyakov AYa, Bogachanov ND Hygienic assessment of actual nutrition of children of school age as a risk factor for the formation of morphological and functional abnormalitie. Zdorov'e naseleniya i sreda obitaniya [Public Health and Life Environment]. 2017; 286 (1): 27-9. Russian.

6. Martinchik AN, Baturin AK, Keshabyants EE, Fatyanova LN, Semenova YaA, Bazarova LB., et al. Dietary intake analysis of Russian children 3-19 years old. Voprosy pitaniya [Problems of nutrition]. 2017;86(4): 50-60. in Russian.

7. Shemetova EV, Boytsova TM Food for schoolchildren in the Primorsky Territory: current state, quality and monitoring. Tekhnika i tekhnologiya pishchevykh proizvodstv. 2017; 45 (2): 112-11. Russian.

8. Kodentsova VM, Risnik DV Vitamin-mineral complexes for children during the period of active social adaptation. Meditsinskiy sovet. 2018; 2: 52-57. DOI: 10.21518/2079-701X-2018-2-52-57. Russian.

9. Karamnova NS, Drapkina OM COVID-19 and nutrition: new emphases, old priorities (review of guidelines). Cardiovascular Therapy and Prevention. 2020; 19(3): 2576. DOI:10.15829/17288800-2020-2576. Russian.

10. Milushkina OYu, Popov VI, Skoblina NA, Markelova SV, Sokolova NV The USE of electronic devices by students, parents and teachers before and after the transition to distance learning. Vestnik Rossiyskogo gosudarstvennogo meditsinskogo universiteta». Bulletin of Russian State Medical University. 2020; 3: 85-91 DOI: 10.24075/vrgmu.2020.037. Russian.

11. Tutelyan VA, Nikityuk DB, Burlyaeva EA, Khotimchenko SA, Baturin AK, Starodubova AV, Kambarov AO, Sheveleva SA, Zhilinskaya NV COVID-19: new challenges for medical science and practical health. Voprosy pitaniia. Problems of Nutrition. 2020; 89 (3): 6-13. DOI: 10.24411/0042-8833-2020-10024. Russian.

\section{Литература}

1. Кучма В.Р., Седова А.С., Степанова М.И. и др. Особенности жизнедеятельности и самочувствия детей и подростков, дистанционно обучающихся во время эпидемии новой коронавирусной инфекции COVID-19. Вопросы школьной и университетской медицины и здоровья. 2020; (2): 4-24.

2. Viner RM, Russell SJ, Croker H, et al. 2020. School closure and management practices during coronavirus outbreaks including COVID-19: a rapid systematic review. Lancet Child Adolesc Health. 2020; (4):397-404.

3. Overview of public health and social measures in the context of COVID-19. Interim guidance. 18 May 2020. Available at: Downloads/WHO-2019-nCoV-PHSM_Overview-2020.1-eng.pdf. Accessed 16 April 2020.

4. Лебедева У.М., Баттахов П.П., Степанов К.М., Лебедева А.М., Занковский С.С., Булгакова Л.И., Винокурова Д.М. Организация питания детей и подростков на региональном уровне. Вопросы питания. 2018; 87(6): 48-56. DOI: 10.24411/0042-8833-2018-10066.

5. Сорокина А.В, Гигуз Т.Л, Поляков А.Я, Богачанов Н.Д. Гигиеническая оценка фактического питания детей школьного возраста как фактора риска формирования морфофункциональных отклонений. Здоровье населения и среда обитания. 2017; 286 (1): 27-9.

6. Мартинчик А.Н, Батурин А.К, Кешабянц Э.Э, Фатьянова Л.Н,
12. Maggini S., Pierre A., Calder P.C. Immune function and micronutrient requirements change over the life course. Nutrients. 2018; 10 (10): 1531. DOI: 10.3390/nu10101531.

13. Miguel Angel Pedraza Zárate. Nutrition in this Pandemic of COVID19. EC Nutrition. 2020; 15(11): 07-08.

14. Laxmi Teja Peela., et al. Nutrition Patterns and their Effects in General Public during Covid-19 Pandemic Lockdown. EC Nutrition. 2020; 15 (7): 01-04.

15. Günay Eskici. Immune System against Covid-19: The Importance of Prebiotics and Probiotics. EC Nutrition. 2020; 15 (8): 04-05.

16. Martinchik AN, Baturin AK, Boeva VS Album of portions of food and dishes. Al'bom porcij produktov i bljud. Moscow, 1995; 65 p. .Russian.

17. Sanitary and epidemiological requirements for the organization of meals for students in educational institutions, institutions of primary andsecondary vocationaleducation.Sanitarno-epidemiologicheskie trebovaniya $\mathrm{k}$ organizatsii pitaniya obuchayushchikhsya $v$ obshcheobrazovatel'nykh uchrezhdeniyakh, uchrezhdeniyakh nachal'nogo i srednego professional'nogo obrazovaniya.: SanPiN 2.4.5.2409-08. Moscow, 2008. Russian.

18. The norms of physiological needs for nutrients and energy for different groups of the population. Normy fiziologicheskikh potrebnostey $\vee$ pishchevykh veshchestvakh $\mathrm{i}$ energii dlya razlichnykh grupp naseleniya.: MR 2.3.1.2432-08. Moscow, 2008. Russian.

19. Specialized diet for children and adults in self-isolation or quarantine at home in connection with COVID-19. Spetsializirovannyy ratsion pitaniya dlya detey i vzroslykh, nakhodyashchikhsya $v$ rezhime samoizolyatsii ili karantina $v$ domashnikh usloviyakh $v$ svyazi s COVID-19.: MR 2.3.0171-20. Moscow: Federal Service for Oversight of Consumer Rights Protection, 2020. Russian.

20. Efimova NV, Myl'nikova IV, Turov VM Nutrition Patterns in Urban and Rural Schoolchildren of Irkutsk Region. Ekologiya cheloveka. Human Ecology. 2020;3: 23-30. Russian.

21. Esaulenko IE, Nastausheva TL, Zhdanova OA, Minakova OV Characterization of the physical development and diet of Voronezh schoolchildren. Voprosy pitaniya. Nutrition issues. 2017; 4(86):8592. Doi:10.24411/0042-8833-2017-00063. Russian.

22. Sekiyama M., Roosita K., Ohtsuka R. Physical growth and diets of school children: Trends from 2001 to 2015 in rural West Java, Indonesia. American journal of human biology. 2018; 2 (30), p. e23089

23. Vieux F., Dubois Ch., Duchene Ch., Darmont N. Nutritional quality of school meals in France: impact of guidelines and the role of protein dishes. Nutrients. 2018; 2(10), p. nu10020205.

Семенова Я.А, Базарова Л.Б., и др. Анализ фактического питания детей и подростков России в возрасте от 3 до 19 лет. Вопросы питания. 2017; 86(4): 60-50.

7. Шеметова Е.В., Бойцова Т.М. Питание школьников Приморского края: современное состояние, качество и мониторинг. Техника и технология пищевых производств. 2017; 45(2): 112-118.

8. Коденцова В.М., Рисник Д.В. Витаминно-минеральные комплексы для детей в период активной социальной адаптации. Медицинский совет. 2018; 2: 52-57. DOI: 10.21518/2079-701X-2018-2-52-57.

9. Карамнова Н.C., Драпкина О.M. COVID-19 и питание: новые акценты, прежние приоритеты (обзор рекомендаций). Кардиоваскулярная терапия и профилактика. 2020;19 (3): 2576. DOI:10.15829/1728-8800-2020-2576

10. Милушкина О.Ю., Попов В.И., Скоблина Н.А., Маркелова С.В., Соколова Н.В. Использование электронных устройств участниками образовательного процесса при традиционной и дистанционной формах обучения. Вестник Российского государственного медицинского университета. 2020; 3: 8591. DOI: $10.24075 /$ vrgmu.2020.037

11. Тутельян В.А., Никитюк Д.Б., Бурляева Е.А., Хотимченко С.А., Батурин А.К., Стародубова А.В., Камбаров А.О., Шевелева С.А., Жилинская H.B. COVID-19: новые вызовы для медицинской 
науки и практического здравоохранения. Вопросы питания. 2020; 89 (3): 6-13. DOI: 10.24411/0042-8833-2020-10024

12. Maggini S., Pierre A., Calder P.C. Immune function and micronutrient requirements change over the life course. Nutrients. 2018; 10 (10): 1531. DOI: 10.3390/nu10101531.

13. 13. Miguel Angel Pedraza Zárate. Nutrition in this Pandemic of COVID19. EC Nutrition. 2020; 15(11): 07-08

14. Laxmi Teja Peela., et al. Nutrition Patterns and their Effects in General Public during Covid-19 Pandemic Lockdown. EC Nutrition. 2020; 15 (7): 01-04.

15. Günay Eskici. Immune System against Covid-19: The Importance of Prebiotics and Probiotics. EC Nutrition. 2020; 15 (8): 04-05.

16. Мартинчик А.Н., Батурин А.К., Боева В.С. Альбом порций продуктов и блюд. Москва. 1995; 65 с.

17. Санитарно-эпидемиологические требования к организации питания обучающихся в общеобразовательных учреждениях, учреждениях начального и среднего профессионального образования: СанПиН 2.4.5.2409-08. М., 2008.

18. Нормы физиологических потребностей в пищевых веществах и энергии для различных групп населения: МP 2.3.1.2432-08.
Москва, 2008.

19. Специализированный рацион питания для детей и взрослых, находящихся в режиме самоизоляции или карантина в домашних условиях в связи с COVID-19: MP 2.3.0171-20. Москва: Федеральная служба по надзору в сфере защиты прав потребителей человека, 2020.

20. Ефимова Н. В., Мыльникова И. В., Туров В. М. Питание школьников, проживающих на городских и сельских территориях Иркутской области. Экология человека. 2020;3: 23-30.

21. Есауленко И. Э., Настаушева Т. Л., Жданова О. А., Минакова О. В. Характеристика физического развития и режима питания школьников Воронежа. Вопросы питания. 2017; 4(86): 85-92. DOI:10.24411/0042-8833-2017-00063.

22. Sekiyama M., Roosita K., Ohtsuka R. Physical growth and diets of school children: Trends from 2001 to 2015 in rural West Java, Indonesia. American journal of human biology. 2018; 2 (30), p. e23089

23. Vieux F., Dubois Ch., Duchene Ch., Darmont N. Nutritional quality of school meals in France: impact of guidelines and the role of protein dishes. Nutrients. 2018; 2(10), p. nu10020205 